\title{
Toxoplasma gondii: isolation, biological and molecular characterisation of samples from free-range Gallus gallus domesticus from countryside Southeast Brazil
}

\author{
Toxoplasma gondii: isolamento, caracterização biológica e molecular de amostras de \\ Gallus gallus domesticus no interior do Sudeste brasileiro
}

\begin{abstract}
Tamiris Cristine Ribeiro Ferreira ${ }^{1,2}$; Julyana Cerqueira Buery ${ }^{1,2}$; Narcisa Imaculada Brant Moreira ${ }^{1,2}$; Claudiney Biral Santos ${ }^{2}$; Júlia Gatti Ladeia Costa ${ }^{3}$; Lorena Velozo Pinto ${ }^{3}$; Ramon Castro de Araújo Baraviera ${ }^{3}$; Ricardo Wagner Almeida Vitor ${ }^{3}$; Blima Fux ${ }^{1,2 *}$
\end{abstract}

\begin{abstract}
${ }^{1}$ Programa de Pós-graduação em Doenças Infecciosas, Núcleo de Doenças Infecciosas, Universidade Federal do Espírito Santo UFES, Vitória, ES, Brasil

${ }^{2}$ Unidade de Medicina Tropical, Departamento de Patologia, Universidade Federal do Espírito Santo - UFES, Vitória, ES, Brasil

${ }^{3}$ Departamento de Parasitologia, Universidade Federal de Minas Gerais - UFMG, Belo Horizonte, MG, Brasil
\end{abstract}

Received November 16, 2017

Accepted March 16, 2018

\begin{abstract}
Toxoplasma gondii presents a high prevalence worldwide, infecting several animals. Felines are considered the definitive hosts and among the intermediate hosts we highlight mammals and birds. The man can become infected by ingesting tissue cysts present in birds and mammals. Biological and molecular aspects of $T$. gondii allows a better understanding of the epidemiology of toxoplasmosis. This work is a serologic screening of 58 chickens grown (Gallus gallus domesticus) for human consumption in Espírito Santo State, by means of indirect haemagglutination assay (IHA). Thirteen chickens tested positive for anti-T. gondii antibodies. The heart and brain of five positive chickens were harvested, treated with pepsin and inoculated separately, in two Swiss mice, intraperitoneally. Tachyzoites were observed in the peritoneum of all the animals, between seven and 10 days after the inoculum. Ten isolates were obtained and biologically characterised in BALB/c mice inoculated with $10^{1}$ to $10^{4}$ tachyzoites. All isolates were classified as virulent or intermediately virulent. Isolates were genotyped by means of polymerase chain reaction-restriction fragment length polymorphism (PCR-RFLP) analysis, revealing three different genotypes. None of the isolates exhibited the clonal type I, II or III genotype. No genotypic differences were observed between the isolates from the brain or heart from the same bird.
\end{abstract}

Keywords: Toxoplasma gondii, isolation, virulence, genotyping.

\section{Resumo}

Toxoplasma gondii apresenta alta prevalência mundial, capaz de infectar diversos animais. Felinos são considerados os hospedeiros definitivos e entre os hospedeiros intermediários destacamos os mamíferos e as aves. O homem pode se infectar ingerindo cistos teciduais presentes na carne das aves e mamíferos. O conhecimento dos aspectos biológicos e moleculares do parasito possibilitam melhor entendimento da epidemiologia da toxoplasmose. Neste trabalho foi realizada triagem sorológica por hemaglutinação indireta $(\mathrm{HI})$ em 58 galinhas caipiras (Gallus gallus domesticus) utilizadas para consumo humano, provenientes do estado do Espírito Santo, Brasil. Treze galinhas apresentaram sorologia positiva para T. gondii. O coração e o cérebro de cinco galinhas positivas foram colhidos, tratados com pepsina e inoculados separadamente, em dois camundongos Swiss, por via intraperitoneal. Observou-se taquizoítos no peritônio de todos os camundongos, entre sete e 10 dias após o inóculo. Foram obtidos 10 novos isolados de T. gondii os quais foram estudados em camundongos $\mathrm{BALB} / \mathrm{C}$ inoculados com $10^{1}$ a $10^{4}$ taquizoítos por animal. Todos os isolados foram considerados virulentos ou de virulência intermediária. A caracterizaçáo molecular dos isolados, realizada por PCR-RFLP, demonstrou a

*Corresponding author: Blima Fux. Universidade Federal do Espírito Santo

- UFES, Av. Marechal Campos, 1468, Maruípe, CEP 29040-090, Vitória, ES,

Brasil.e-mail: blimafux@yahoo.com.br 
ocorrência de três genótipos distintos. Nenhum isolado apresentou genótipo clonal ou linhagem clonal do Brasil. Não foi observada diferença molecular (PCR-RFLP) entre os isolados obtidos a partir do cérebro ou do coraçáo da mesma ave. Dois isolados já haviam sido relatados na literatura como causadores de doenças em humanos.

Palavras-chave: Toxoplasma gondii, isolamento, caracterização biológica, genotipagem.

\section{Introduction}

Toxoplasma gondii is a pathogenic agent with significant impacts in human and veterinary medicine. According to estimates, one-third of the human population is infected with the parasite (WEISS \& DUBEY, 2009). Felids are the only known definitive hosts of $T$. gondii, which means that the sexual cycle of the parasite occurs in only these animals. Among the most important intermediate hosts are mammals, including humans, and birds. Free-range chickens (Gallus gallus domesticus) habitually scratch the soil in search of food and are thus prone to acquire infection in an environment potentially contaminated with oocysts, one of the infective forms of $T$. gondii. For this reason, this bird species is considered an excellent indicator of environmental contamination (DUBEY et al., 2007b).

Toxoplasma gondii has a highly clonal population structure in the Northern Hemisphere (DARDÉ, 2008), whereas nonclonal strains, i.e., atypical genotypes, are predominant in South America (SILVA et al., 2014; SHWAB et al., 2014). Thus, the genetic diversity of the parasite typically follows a geographical distribution. While few genotypes dominate in the Northern Hemisphere, hundreds of genotypes coexist in the Southern Hemisphere. Despite none being notably dominant over others, some genotypes have a higher relative frequency (SHWAB et al., 2014). In Brazil, more atypical strains exist (DUBEY \& SU, 2009; CARNEIRO et al., 2013; SILVA et al., 2014), a situation related to several factors, such as geographical range, tropical climate, rich fauna and diverse transmission routes (FERREIRA et al., 2006). Furthermore, four genotypes with wide circulation and described in different hosts in Brazil have been proposed as Brazilian clonal lineages. These lineages are termed BRI, BRII, BRIII and BRIV and are distinct from the archetypal lineages types I, II and III (PENA et al., 2008).

One classic means of categorising T. gondii virulence is by inoculating the parasite in laboratory mice. According to mortality in mice, $T$. gondii is classified as virulent, intermediately virulent or avirulent. Clonal strains of type I are virulent, independent of the inoculated dose, whereas the avirulent strains (type III) establish a chronic infection at doses below $10^{3}$ tachyzoites (SILVA et al., 2014).

Thus, the objective of the present study was to isolate $T$. gondii from the tissues of free-range chickens from Espírito Santo State (ES), Southeast Brazil, and to follow up by assessing the virulence and genotyping from the isolates. The knowledge of the biological and molecular aspects of the parasite is important for the epidemiology of toxoplasmosis disease.

\section{Materials and Methods}

A total of 58 chickens (Gallus gallus domesticus) grown for human consumption in Espírito Santo State from the municipalities of Cariacica $(\mathrm{n}=8)$, Viana $(\mathrm{n}=16)$ and Venda Nova do Imigrante $(\mathrm{n}=34)$, ES, Brazil, were evaluated in the period of January to October 2014. Chickens sera were obtained from whole blood samples, collected in tubes without anticoagulant. First, each serum was submitted to indirect haemagglutination assays (IHAs) (Imuno-HAI Toxoplasmose WAMA , Sáo Carlos, São Paulo, Brazil) according to the manufacturer's instructions. Seropositive chickens were sacrificed by cervical dislocation, and the brains and hearts were collected. Organs were stored at $4{ }^{\circ} \mathrm{C}$ until used.

Toxoplasma gondii strains were isolated in a bioassay of the brains and hearts of five seropositive chickens. Isolation was not successful for the eight remaining chickens. Slaughtering was made by the chicken's producer for their own consumption. After that, heart and brain were removed, packed in individual plastic bags, and transported on ice to the Laboratory of Toxoplasmosis, located at the Instituto de Ciências Biológicas of the Universidade Federal de Minas Gerais (ICB - UFMG). Full organs were individually macerated and digested with pepsin solution (pepsin, $2.6 \mathrm{~g} ; \mathrm{NaCl}, 5.0 \mathrm{~g} ; \mathrm{HCl}, 7.0 \mathrm{~mL}$; and water to make $500 \mathrm{~mL}$ ). The homogenate was incubated at $37^{\circ} \mathrm{C}$ in a shaking water bath for $1 \mathrm{~h}$, washed twice by centrifugation $(1200 \times \mathrm{g}$ for $10 \mathrm{~min})$ with sterile phosphate-buffered saline (PBS, $\mathrm{pH}$ 7.2). The final sediment was suspended with $2 \mathrm{~mL}$ of PBS, $\mathrm{pH} 7.2$ containing 1000 units of penicillin and $100 \mu \mathrm{g}$ of streptomycin per milliliter and inoculated intraperitoneally into two Swiss mice (DUBEY, 1998; CARNEIRO et al., 2013). Toxoplasmosis in mice was confirmed when tachyzoites were found in the lungs, or cysts in the brain by optical microscopy.

T. gondii virulence in mice was determined in accordance with Ferreira et al. (2001). Four groups of five mice (twenty female $\mathrm{BALB} / \mathrm{c}$ mice infected with each T. gondii isolate) were infected intraperitoneally with increasing doses of $10^{1}, 10^{2}, 10^{3}$ and $10^{4}$ tachyzoites of each isolate in a volume of $0.2 \mathrm{~mL}$. To obtain tachyzoites, Swiss mice were infected intraperitoneally with 300-500 brain cysts with each T. gondii isolate. Seven days after inoculation, the parasites were washed and collected from the peritoneal cavity with PBS $\mathrm{pH}$ 7.2. The exsudate were centrifuged and tachyzoites filtered in $3 \mu \mathrm{m}$ polycarbonate membrane. The number of tachyzoites was adjusted and used for virulence assay (fresh tachyzoites) or stored as frozen pellets at $-20^{\circ} \mathrm{C}$, until DNA extraction for genotyping study. Five control animals were inoculated with $0.2 \mathrm{~mL}$ of sterile PBS $\mathrm{pH} 7.2$. Mice mortality was daily observed throughout 30 days, when the survivors were tested for anti-T. gondii IgG antibodies by enzyme-linked 
immunosorbent assay (ELISA) and brain cysts, as described by Ferreira et al. (2001).

Toxoplasma gondii isolates were genotyped by means of polymerase chain reaction-restriction fragment length polymorphism (PCRRFLP) analysis using primer pairs for 12 different loci: SAG1, SAG2-5'+3', SAG2-new, SAG3, BTUB, GRA6, c22-8, c22-9, CS3, L358, PK1 and Apico (SU et al., 2010). The RH (clonal type I), ME49 (clonal type II) and VEG (clonal type III) strains were used as controls (FUX et al., 2003). The profiles of the bands obtained after digestion with specific restriction endonucleases (SU et al., 2010) were analysed in polyacrylamide gels stained with silver nitrate and then compared with the profiles of reference strains. The obtained results were analysed in the virtual database ToxoDB (www.toxodb.org) and compared with the genotypes of the deposited strains (SU et al., 2010).

\section{Ethics}

The present study has been approved by the Animal Ethics Committee of the Federal University of Espírito Santo (Comitê de Ética em Experimentação Animal, Universidade Federal do Espírito Santo - CEUA/UFES 080/2011).

\section{Results}

\section{Serology}

All chicken from the municipalities of Cariacica and Viana exhibited negative IHA results. Of the 34 chickens from Venda Nova do Imigrante, 13 (38\%) tested positive for anti-T. gondii IgG.

\section{Isolation and characterisation of T. gondii strains}

The isolation of T. gondii was successful; all inoculated Swiss mice died and/or developed ascites with tachyzoites at 7 to $15 \mathrm{~d}$ post-inoculation. Five isolates were obtained from the brains (TgCkBrEs1b to TgCkBrEs5b) and five from the hearts ( $\mathrm{TgCkBrEs} 1 \mathrm{~h}$ to $\mathrm{TgCkBrEs} 5 \mathrm{~h}$ ). Among the isolates obtained in this study, none were considered avirulent, and only two of the heart samples ( $\mathrm{TgCkBrEs} 1 \mathrm{~h}$ and $\mathrm{TgCkBrEs} 5 \mathrm{~h}$ ) were considered intermediately virulent (Table 1 ), even though survival only occurred at the lowest dose ( $10^{1}$ tachyzoites).

\section{Genotyping of T. gondii isolates}

All ten isolates obtained were successfully genotyped by the 12 molecular markers described by Su et al. (2010). Three different genotypes have already been described in the literature (Table 2). The isolates $\mathrm{TgCkBrEs} 1 \mathrm{~b}$ and $\mathrm{TgCkBrEs} 1 \mathrm{~h}$ exhibited genotype \#206 (ToxoDB). The TgCkBrEs2b, TgCkBrEs2h, TgCkBrEs3b and $\mathrm{TgCkBrEs} 3 \mathrm{~h}$ isolates exhibited genotype \#36 (ToxoDB), and the TgCkBrEs4b, TgCkBrEs4h, TgCkBrEs5b and TgCkBrEs5h isolates exhibited genotype \#6 (ToxoDB). No difference was observed in the genotypes between the isolates obtained from the brain or heart of the same bird.

\section{Discussion}

Of the free-range chicken farms in rural areas of Espírito Santo State, no cases of seropositive animals were found in the municipalities of Cariacica and Viana. The present study was developed in the mountainous region of the state (Venda Nova do Imigrante) for which no previous data on avian toxoplasmosis were available. In Venda Nova do Imigrante, 38\% of the evaluated birds exhibited specific antibodies against $T$. gondii, our results were similar compared to results from backyard chickens in the metropolitan area of Recife (FERNANDES et al., 2016) and in the semiarid region of the state of Pernambuco (SÁ et al., 2017). Venda Nova do Imigrante also has a high prevalence of ocular toxoplasmosis, with $11.27 \%$ positive cases (ABREU et al., 1998), and is likely a favourable site for the presence and transmission of the parasite, as the mean prevalence of ocular toxoplasmosis in Brazil is $1.6 \%$ (ZANETTI \& PLETSCH, 2007).

Table 1. Site of isolation and classification of virulence by mortality in BALB/c mice inoculated with decreasing doses of Toxoplasma gondii tachyzoites isolated from free-range chickens in Espírito Santo State, Brazil.

\begin{tabular}{ccccccc}
\hline Isolates & Site of isolation & $\mathbf{1 0}^{\mathbf{4}}$ tach. & $\mathbf{1 0}^{\mathbf{3}}$ tach. & $\mathbf{1 0}^{\mathbf{2}}$ tach. & $\mathbf{1 0}^{\mathbf{1}}$ tach. & Classification of virulence \\
\hline TgCkBrEs1 $\mathbf{b}^{*}$ & $\mathrm{VNI} / \mathrm{I}$ & $5 / 5^{* *}$ & $4 / 4$ & $5 / 5$ & $2 / 2$ & Virulent \\
TgCkBrEs2b & VNI/II & $5 / 5$ & $5 / 5$ & $5 / 5$ & $5 / 5$ & Virulent \\
TgCkBrEs3b & VNI/II & $5 / 5$ & $5 / 5$ & $5 / 5$ & $5 / 5$ & Virulent \\
TgCkBrEs4b & VNI/IV & $5 / 5$ & $5 / 5$ & $5 / 5$ & $5 / 5$ & Virulent \\
TgCkBrEs5b & VNI/IV & $5 / 5$ & $5 / 5$ & $5 / 5$ & $4 / 4$ & Virulent \\
TgCkBrEs1h & VNI/I & $5 / 5$ & $5 / 5$ & $5 / 5$ & $0 / 2$ & Intermediately Virulent \\
TgCkBrEs2h & VNI/II & $5 / 5$ & $5 / 5$ & $2 / 2$ & $2 / 2$ & Virulent \\
TgCkBrEs3h & VNI/II & $5 / 5$ & $5 / 5$ & $5 / 5$ & $3 / 3$ & Virulent \\
TgCkBrEs4h & VNI/IV & $5 / 5$ & $5 / 5$ & $5 / 5$ & $5 / 5$ & Virulent \\
TgCkBrEs5h & VNI/IV & $5 / 5$ & $5 / 5$ & $5 / 5$ & $1 / 3$ & Intermediately Virulent \\
\hline
\end{tabular}

*TgCkBrEsbh: $\mathrm{Tg}=$ Toxoplasma gondii; $\mathrm{Ck}=$ chicken; $\mathrm{Br}=$ Brazil; Es = Espírito Santo State; $\mathrm{b}=\mathrm{brain} ; \mathrm{h}=\mathrm{heart}$ ); VNI/I = Venda Nova do Imigrante, holding I; VNI/II = Venda Nova do Imigrante, holding II; VNI/I V = Venda Nova do Imigrante, holding IV; **Number of BALB/c mice that died/total number of mice inoculated and confirmedly infected (by means of parasitological diagnosis and/or ELISA). 
Table 2. Multilocus genotyping of Toxoplasma gondii isolates from free-range chickens slaughtered in Espírito Santo State, Brazil, by polymerase chain reaction-restriction fragment length polymorphism (PCR-RFLP) analysis.

\begin{tabular}{|c|c|c|c|c|c|c|c|c|c|c|c|c|c|c|}
\hline \multirow[b]{2}{*}{ Isolates } & \multirow[b]{2}{*}{ Virulence } & \multicolumn{11}{|c|}{ Genetic markers } & \multirow[b]{2}{*}{$C S 3$} & \multirow{2}{*}{$\begin{array}{l}\text { ToxoDB- } \\
\text { Genotype }\end{array}$} \\
\hline & & $S A G 1$ & 5'3'SAG2 & $\begin{array}{c}\text { alt } \\
S A G 2 \\
\end{array}$ & $S A G 3$ & BTUB & GRAG & $c 22-8$ & $c 29-2$ & $L 358$ & $P K 1$ & Apico & & \\
\hline RH88 & Virulent & I & I & I & I & I & I & I & I & I & I & I & I & $\# 10$ \\
\hline ME49 & Intermediate & $\mathrm{II} / \mathrm{III}$ & II & II & II & II & II & II & II & II & II & II & II & $\# 1$ \\
\hline VEG & Avirulent & $\mathrm{II} / \mathrm{III}$ & III & III & III & III & III & III & III & III & III & III & III & $\# 2$ \\
\hline TgCkBrEs $1 \mathrm{~b}$ & Virulent & $\mathrm{u}-1$ & I & II & III & III & III & II & III & I & III & I & II & $\# 206$ \\
\hline TgCkBrEs $1 \mathrm{~h}$ & Intermediate & $\mathrm{u}-1$ & I & II & III & III & III & II & III & I & III & I & II & $\# 206$ \\
\hline TgCkBrEs2b & Virulent & I & I & I & III & I & III & II & I & III & I & III & I & $\# 24$ \\
\hline TgCkBrEs2h & Virulent & I & I & I & III & I & III & II & I & III & I & III & I & $\# 24$ \\
\hline TgCkBrEs3b & Virulent & I & I & I & III & I & III & II & I & III & I & III & I & $\# 24$ \\
\hline TgCkBrEs3h & Virulent & I & I & I & III & I & III & II & I & III & I & III & I & $\# 24$ \\
\hline TgCkBrEs $4 \mathrm{~b}$ & Virulent & I & I & I & III & I & II & $\mathrm{u}-1$ & I & I & I & I & I & \#6 \\
\hline TgCkBrEs $4 \mathrm{~h}$ & Virulent & I & I & I & III & I & II & $\mathrm{u}-1$ & I & I & I & I & I & \#6 \\
\hline TgCkBrEs5b & Virulent & I & I & I & III & I & II & $\mathrm{u}-1$ & I & I & I & I & I & $\# 6$ \\
\hline TgCkBrEs5h & Intermediate & I & I & I & III & I & II & $\mathrm{u}-1$ & I & I & $\mathrm{I}$ & I & I & $\# 6$ \\
\hline
\end{tabular}

The IHA method was chosen for the detection of specific antibodies against T. gondii because it exhibits good agreement with the modified agglutination test (MAT) (82\%) (BELTRAME et al., 2012). IHA is considered a reliable test, in addition to the advantages of low cost and easy application compared to other methods (CASARTELLI-ALVES et al., 2014).

Toxoplasma gondii was isolated from all chickens submitted to the bioassay. According to Dubey et al. (1998), T. gondii cysts are more abundant in neural, muscle and cardiac tissue. Accordingly, the heart of the chickens was chosen for isolation due to the heavy parasitism and because it is considered a culinary delicacy in several regions of Brazil. To ensure higher chances of isolation, the brains of the animals were also used. Aigner et al. (2010) have shown by means of real-time PCR that no significant difference exists in the number of parasites per gram of cardiac and neural tissue in seropositive birds.

According to Dubey et al. (2005), the success of isolation depends on the number of inoculated animals, the amount of tissue used and the concentration of the parasite in the tissues. The success of isolation of the parasites in the present work corroborates these data. The frequency of positivity for isolation of T. gondii from chickens typically ranges from 28.4\% (OLIVEIRA et al., 2009) to $70 \%$ (DUBEY et al., 2002). Cases with a $100 \%$ success rate of isolation, as in the present work, are rare.

Depending on its lethality in mice, $T$. gondii can be considered virulent, avirulent or intermediately virulent. Type I clonal strains, such as the RH strain, are always virulent, independent of the dose. Mice die even with an inoculum of a single tachyzoite. On the other hand, type II clonal strains establish a chronic infection by producing tissue cysts, even at doses as high as $10^{3}$ tachyzoites. Type II clonal strains exhibit intermediate virulence (FERREIRA et al., 2001). All isolates from the present work were virulent, except for $\mathrm{TgCkBrEs} 1 \mathrm{~h}$ and $\mathrm{TgCkBrEs} 5 \mathrm{~h}$, which were considered intermediately virulent. These results agree with the observations of Dubey et al. (2003) and Beltrame et al. (2012), who have shown that mouse-virulent T. gondii strains circulate in asymptomatic vertebrate hosts in Brazil.

According to Gilbert et al. (2008), a predominance of virulent T. gondii strains exist in Brazil compared to Europe, where clonal genotypes are predominant. That finding agrees with the results found in the present work. The authors also reported that the severity of cases of ocular toxoplasmosis is higher in Brazil than in Europe, which suggests that the observations of the experimental model could be applied to humans.

The isolates obtained from the different organs (heart and brain) within the same chicken did not differ with respect to molecular characterisation. Slightly different phenotypic differences were found, i.e., earlier death in animals inoculated with chicken brain (data not shown) and all isolates from the brain being classified as virulent. Thus, due to phenotypic similarity and genetic identity, we can simplify the nomenclature of the isolates and describe them as TgCkBrEs1, TgCkBrEs2, TgCkBrEs3, TgCkBrEs 4 and $\mathrm{TgCkBrEs} 5$. For a deeper understanding of the isolates, Dubey et al. (2008a) have suggested that cases where phenotypic characterisation is different from the molecular characterisation be submitted to DNA sequencing to determine whether the isolates are, in fact, identical or to spot where the differences occur. Another possibility is to assess the diversity of the ROP5, ROP16, ROP17 and ROP18 alleles with respect to virulence, as suggested by Shwab et al. (2016).

Despite the possibility of co-infection by two different $T$. gondii strains in the same host, as reported by Dubey et al. (2007a), such co-infection was not observed in the present study. The genotypes isolated from different chickens within the same municipality exhibited different genotypes. This result is similar to showed in St. Kitts, West Indies, that reveal a greater genetic diversity of strains circulating on the island (HAMILTON et al., 2017). The isolate $\mathrm{TgCkBrEs} 1$ exhibited the same genotype as $\mathrm{TgCkBrRj} 3$ (according to the ToxoDB), which was obtained from a free-range chicken from the municipality of Rio Bonito, Rio de Janeiro State, Brazil. This same genotype (\#206 ToxoDB) has also been described in a 
free-range chicken from the municipality of Colatina in Espírito Santo State (PENA et al., 2013) and in an isolate from the blood of a new-born with congenital toxoplasmosis in Minas Gerais State (CARNEIRO et al., 2013). Considering the distance between the cited regions, this occurrence provides evidence of a common strain circulating throughout the Southeast Region of Brazil. The TgCkBrEs2 and TgCkBrEs3 isolates are similar, and their genotype (\#36 ToxoDB) has already been described in G. gallus in Rio de Janeiro State (DUBEY et al., 2008b).

Two further isolates described in the present study, i.e., TgCkBrEs4 and $\mathrm{TgCkBrEs} 5$, are considered similar genotypes (genotype \#6 ToxoDB). This genotype, also known as BrI, was previously identified in chickens, cats and dogs in Brazil (PENA et al., 2008). Ferreira et al. (2011) have described an isolate with a genotype like that of the two isolates mentioned above, which were obtained from a 45-year-old HIV-positive patient with neurotoxoplasmosis characterised by diffuse encephalitis. Even when not clear whether a given $T$. gondii isolate exhibits the same virulent or avirulent behaviour in humans as in mice (DARDÉ, 2008; BOOTHROYD \& GRIGG, 2002), the discovery of these isolates in humans deserves attention, as these are atypical strains and can generate new mechanisms of pathogenicity. Since undercooked heart from chicken is a delicacy enjoyed both in Espírito Santo and other brazilian states, it is probable that these animals may be carriers of highly pathogenic strains for humans in the region.

As for the CS3 marker, all five isolates exhibited allele I or II, and with respect to virulence, none were considered avirulent, thus suggesting a relation between the presence of allele I and II of the CS3 marker and virulence in mice, as described previously (KHAN et al., 2005; PENA et al., 2008; SILVA et al., 2014).

\section{Conclusion}

Free-range chickens were successfully used as sentinels of environmental infection by $T$. gondii. The animals exhibited high tissue parasitism, which facilitates isolation via bioassays in mice. Genotypes were found that have been described previously from human infections in the same region of Brazil (Southeast), and their biological characterisation revealed that these strains were virulent or intermediately virulent. No preference of the different strains for different tissues was found in the chickens.

\section{Acknowledgements}

We sincerely thank the scientifical support of the staff of the Toxoplasmosis Laboratory of Universidade Federal de Minas Gerais and the staff of the Tropical Medicine Unit of the Universidade Federal do Espírito Santo. Our gratefulness for the CAPES, for being the financial support of this study.

\section{References}

Abreu MT, Boni D, Belford R Jr, Passos A, Garcia AR, Muccioli C, et al. Toxoplasmose ocular em Venda Nova do Imigrante, ES, Brasil. Arq Bras Oftalmol 1998; 61(5): 540-545.

Aigner CP, Silva AV, Sandrini F, Osório PS, Poiares L, Largura A. Realtime PCR-based quantification of Toxoplasma gondii in tissue samples of serologically positive outdoor chickens. Mem Inst Oswaldo Cruz 2010, 105(7): 935-937. http://dx.doi.org/10.1590/S0074-02762010000700018. PMid:21120368.

Beltrame MA, Pena HF, Ton NC, Lino AJ, Gennari SM, Dubey JP, et al. Seroprevalence and isolation of Toxoplasma gondii from free-range chickens from Espírito Santo state, southeastern Brazil. Vet Parasitol 2012; 188(3-4): 225-230. http://dx.doi.org/10.1016/j.vetpar.2012.03.053. PMid:22541793.

Boothroyd JC, Grigg ME. Population biology of Toxoplasma gondii and its relevance to human infection: do different strains cause different disease? Curr Opin Microbiol 2002; 5(4): 438-442. http://dx.doi.org/10.1016/ S1369-5274(02)00349-1. PMid:12160866.

Carneiro AC, Andrade GM, Costa JG, Pinheiro BV, Vasconcelos-Santos DV, Ferreira AM, et al. Genetic characterization of Toxoplasma gondii revealed highly diverse genotypes for isolates from newborns with congenital toxoplasmosis in Southeastern Brazil. J Clin Microbiol 2013; 51(3): 901-907. http://dx.doi.org/10.1128/JCM.02502-12. PMid:23284022.

Casartelli-Alves L, Boechat VC, Macedo-Couto R, Ferreira LC, Nicolau JL, Neves LB, et al. Sensitivity and specificity of serological tests, histopathology and immunohistochemistry for detection of Toxoplasma gondii infection in domestic chickens. Vet Parasitol 2014; 204(3-4): 346351. http://dx.doi.org/10.1016/j.vetpar.2014.05.039. PMid:24953750.

Dardé ML. Toxoplasma gondii, "new" genotypes and virulence. Parasite 2008; 15(3): 366-371. http://dx.doi.org/10.1051/parasite/2008153366. PMid:18814708.

Dubey JP, Applewhaite L, Sundar N, Velmurugan GV, Bandini LA, Kwok OC, et al. Molecular and biological characterization of Toxoplasma gondii isolates from free-range chickens from Guyana, South America, identified several unique and common parasite genotypes. Parasitology 2007a 134(11): 1559-1565. http://dx.doi.org/10.1017/S0031182007003083. PMid:17572931.

Dubey JP, Bandini LA, Webb DM, Sundar N, Velmurugan GV, Kwok OC, et al. Endemic avian toxoplasmosis on a farm in Illinois: clinical disease, diagnosis, biologic and genetic characteristics of Toxoplasma gondii isolates from chicken (Gallus domesticus), and a goose (Anser anser). Vet Parasitol 2007b; 148(3-4): 207-212. http://dx.doi.org/10.1016/j. vetpar.2007.06.033. PMid:17656021.

Dubey JP, Graham DH, Blackston CR, Lehmann T, Gennari SM, Ragozo AM, et al. Biological and genetic characterisation of Toxoplasma gondii isolates from chickens (Gallus domesticus) from São Paulo, Brazil: unexpected findings. Int J Parasitol 2002; 32(1): 99-105. http://dx.doi. org/10.1016/S0020-7519(01)00364-2. PMid:11796127.

Dubey JP, Lindsay DS, Speer CA. Structures of Toxoplasma gondii tachyzoites, bradyzoites, and sporozoites and biology and development of tissue cysts. Clin Microbiol Rev 1998; 11(2): 267-299. PMid:9564564.

Dubey JP, Su C. Population biology of Toxoplasma gondii: what's out and where did they come from. Mem Inst Oswaldo Cruz 2009; 104(2): 190-195. http://dx.doi.org/10.1590/S0074-02762009000200011. PMid:19430643.

Dubey JP, Sundar N, Hill D, Velmurugan GV, Bandini LA, Kwok OC, et al. High prevalence and abundant atypical genotypes of Toxoplasma gondii isolated from lambs destined for human consumption in the USA. Int J Parasitol 2008a; 38(8-9): 999-1006. http://dx.doi.org/10.1016/j. ijpara.2007.11.012. PMid:18191859.

Dubey JP, Velmurugan GV, Chockalingam A, Pena HF, de Oliveira LN, Leifer CA, et al. Genetic diversity of Toxoplasma gondii isolates from 
chickens from Brazil. Vet Parasitol 2008b; 157(3-4): 299-305. http:// dx.doi.org/10.1016/j.vetpar.2008.07.036. PMid:18804329.

Dubey JP, Venturini MC, Venturini L, Piscopo M, Graham DH, Dahl E, et al. Isolation and genotyping of Toxoplasma gondii from free-ranging chickens from Argentina. J Parasitol 2003; 89(5): 1063-1064. http:// dx.doi.org/10.1645/GE-126. PMid:14627159.

Dubey JP. Refinement of pepsin digestion method for isolation of Toxoplasma gondii from infected tissues. Vet Parasitol 1998; 74(1): 75-77. http://dx.doi.org/10.1016/S0304-4017(97)00135-0. PMid:9493311.

Dubey JR, Bhaiyat MI, de Allie C, Macpherson CN, Sharma RN, Sreekumar $\mathrm{C}$, et al. Isolation, tissue distribution, and molecular characterization of Toxoplasma gondii from chickens in Grenada, West Indies. J Parasitol 2005; 91(3): 557-560. http://dx.doi.org/10.1645/GE-463R. PMid:16108546.

Fernandes MFTS, Cavalcanti EFTSF, Silva JG, Mota AR, Souza OL No, Santos AS, et al. Occurrence of anti-Toxoplasma gondii antibodies and parasite DNA in backyard chicken breeding in Northeast, Brazil. Rev Bras Parasitol Vet 2016; 25(1): 105-108. http://dx.doi.org/10.1590/ S1984-29612016012. PMid:27007250.

Ferreira AM, Martins MS, Vitor RWA. Virulence for BALB/c mice and antigenic diversity of eight Toxoplasma gondii strains isolated from animals and humans in Brazil. Parasite 2001; 8(2): 99-105. http://dx.doi. org/10.1051/parasite/2001082099. PMid:11474987.

Ferreira AM, Vitor RW, Gazzinelli RT, Melo MN. Genetic analysis of natural recombinant Brazilian Toxoplasma gondii strains by multilocus PCRRFLP. Infect Genet Evol 2006; 6(1): 22-31. http://dx.doi.org/10.1016/j. meegid.2004.12.004. PMid:16376837.

Ferreira IMR, Vidal JE, Mattos CC, Mattos LC, Qu D, Su C, et al. Toxoplasma gondii isolates: multilocus RFLP-PCR genotyping from human patients in São Paulo state, Brazil identified distinct genotypes. Exp Parasitol 2011; 129(2): 190-195. http://dx.doi.org/10.1016/j. exppara.2011.06.002. PMid:21741380.

Fux B, Rodrigues CV, Portela RW, Silva NM, Su C, Sibley D, et al. Role of cytokines and major histocompatibility complex restriction in mouse resistance to infection with a natural recombinant strain (type I-III) of Toxoplasma gondii. Infect Immun 2003; 71(11): 6392-6401. http://dx.doi. org/10.1128/IAI.71.11.6392-6401.2003. PMid:14573660.

Gilbert RE, Freeman K, Lago EG, Bahia-Oliveira LM, Tan HK, Wallon $\mathrm{M}$, et al. Ocular sequelae of congenital toxoplasmosis in Brazil compared with Europe. PLoS Negl Trop Dis 2008; 2(8): e277. http://dx.doi. org/10.1371/journal.pntd.0000277. PMid:18698419.

Hamilton CM, Kelly PJ, Boey K, Corey TM, Huynh H, Metzler D, et al. Predominance of atypical genotypes of Toxoplasma gondii in free-roaming chickens in St. Kitts, West Indies. Parasit Vectors 2017; 10(1): 104. http:// dx.doi.org/10.1186/s13071-017-2019-6. PMid:28241777.
Khan A, Taylor S, Su C, Mackey AJ, Boyle J, Cole R, et al. Composite genome map and recombination parameters derived from three archetypal lineages of Toxoplasma gondii. Nucleic Acids Res 2005; 33(9): 2980-2992. http://dx.doi.org/10.1093/nar/gki604. PMid:15911631.

Oliveira LN, Costa LM Jr, Melo CF, Ramos Silva JC, Bevilaqua CM, Azevedo SS, et al. Toxoplasma gondii isolates from free-range chickens from the Northeast region of Brazil. J Parasitol 2009; 95(1): 235-237. http://dx.doi.org/10.1645/GE-1730.1. PMid:18578589.

Pena HFJ, Gennari SM, Dubey JP, Su C. Population structure and mousevirulence of Toxoplasma gondii in Brazil. Int J Parasitol 2008; 38(5): 561 569. http://dx.doi.org/10.1016/j.ijpara.2007.09.004. PMid:17963770.

Pena HFJ, Vitaliano SN, Beltrame MA, Pereira FE, Gennari SM, Soares RM. PCR-RFLP genotyping of Toxoplasma gondii from chickens from Espírito Santo state, Southeast region, Brazil: new genotypes and a new SAG3 marker allele. Vet Parasitol2013; 192(1-3): 111-117. http://dx.doi. org/10.1016/j.vetpar.2012.10.004. PMid:23116899.

Sá Q, Ochiai E, Tiwari A, Mullins J, Shastri N, Mercier C, et al. Determination of a Key Antigen for Immunological Intervention To Target the Latent Stage of Toxoplasma gondii. J Immunol 2017; 198(11): 44254434. http://dx.doi.org/10.4049/jimmunol.1700062. PMid:28446567.

Shwab EK, Jiang T, Pena HF, Gennari SM, Dubey JP, Su C. The ROP18 and ROP5 gene allele types are highly predictive of virulence in mice across globally distributed strains of Toxoplasma gondii. Int J Parasitol 2016; 46(2): 141-146. http://dx.doi.org/10.1016/j.ijpara.2015.10.005. PMid:26699401.

Shwab EK, Zhu XQ, Majumdar D, Pena HF, Gennari SM, Dubey JP, et al. Geographical patterns of Toxoplasma gondii genetic diversity revealed by multilocus PCR-RFLP genotyping. Parasitology 2014; 141(4): 453-461. http://dx.doi.org/10.1017/S0031182013001844. PMid:24477076.

Silva LA, Andrade RO, Carneiro AC, Vitor RW. Overlapping Toxoplasma gondii genotypes circulating in domestic animals and humans in Southeastern Brazil. PLoS One 2014; 9(2): e90237. http://dx.doi.org/10.1371/journal. pone.0090237. PMid:24587295.

Su C, Shwab EK, Zhou P, Zhu XQ, Dubey JP. Moving towards an integrated approach to molecular detection and identification of Toxoplasma gondii. Parasitology 2010; 137(1): 1-11. http://dx.doi.org/10.1017/ S0031182009991065. PMid:19765337.

Weiss LM, Dubey JP. Toxoplasmosis: A history of clinical observations. Int J Parasitol 2009; 39(8): 895-901. http://dx.doi.org/10.1016/j. ijpara.2009.02.004. PMid:19217908.

Zanetti L, Pletsch MU. Prevalência de toxoplasmose ocular em um consultório oftalmológico do município de Ijuí-RS. Rev Contexto \& Saúde 2007; 7(13): 15-20. 